\title{
Utilizing Alumina-Silica Enriched Bricks Debris Determining End Product of ML-CL Fill Soil: Advanced Stabilization Practices with Innovating Discarded Material
}

\author{
Muhammad Afzaal $^{1}$, Ihsanullah Shah ${ }^{2}$, Muhammad Sheraz $^{3}$, Sher Shah ${ }^{4}$, Arif Rashid ${ }^{5}$, \\ Masaud Ahmad Khan ${ }^{6}$, Mateeullah ${ }^{7}$ \\ 1,3,5,6 CECOS University, Peshawar, Pakistan \\ ${ }^{2}$ University of Haripur, Haripur, Pakistan \\ ${ }^{4}$ Central Power Generation Company Genco-11, Guddu, Pakistan \\ ${ }^{7}$ Sarhad University of Science and Information Technology, Peshawar, Pakistan
}

\begin{abstract}
Testing soil and knowing its strength parameters is one of the basic components in construction. Testing of fill soil is carried out to find whether the existing soil can endure the burden of structure withheld upon it or not. In the case of weak soil, one can find it difficult to pursue construction or any development project. While talking of solutions, there are many methods to improve its strength and properties: one of them which we decided to work on is 'stabilization of fill soil using bricks waste which is normally easily available material. The main objective of our test is to check the effectiveness of bricks waste on the mechanical properties of filling material. The testing comprised of performing Atterberg limits, Unconfined Compression, Direct Shear, Sieve Analysis, Moisture Dry Density, and Permeability. The Bricks waste passing no. 40 sieve is mixed with fill soil and testing on different proportions i.e. 0, 5, 10, 15 and 20 percent was carried out. The summary was prepared showed improvement in soil regarding the shear strength and toughness as the Plasticity Index of the soil was improved. The unconfined compression test results show a pattern in which the peak stress is increased as we move to higher percentages. Also, the moisture content is increased for this test because the brick debris absorbed water. Direct shear test on percentages up to $15 \%$ showed that the peak shear stress increased, which indicates that on higher percentages the sample took more load as compared to small percentages. Moisture Dry Density relationship provides a clear indication of an increase in density of soil as moved to higher percentages and decrease in Optimum Moisture Content which suggests that, clay absorbs more water content as compared to brick debris.
\end{abstract}

Index Terms — Fill Soil, Bricks Debris, Stabilization, Shear Strength, Atterberg Limits, Compaction

Received: 03 February 2021; Accepted: 28 April 2021; Published: 08 June 2021

(C) 2021 JITDETS. All rights reserved.

\section{INTRODUCTION}

Soil stabilization is the process to enhance the physical properties of soil by alteration and thus the stabilization can increase its engineering properties of soil as the shear strength of soil, ground improvement to support sub-grade, this can increase structural integrity, load-bearing capacity, and aging control of soil [1]. Soil stabilization is required when the sub-grade material available is not suitable to meet the purpose. It reduces the shear strength, permeability, construction, and compressibility of soil thus for stabilization of soil clay and granular soil can be used [2]. The degree of stability depends upon the shear strength and load-bearing. The soil is utilized for different engineering properties on parking areas, sub-soil, site improvement projects, and the development of airports [3].

Bricks waste is one of the common materials, which is formed after the production of bricks that is highly used in building construction and demolition $[4,5]$. The stabilization of waste will be reducing the cost of

\footnotetext{
${ }^{*}$ Corresponding author: Muhammad Afzaal

†Email: moinuddin@ump.edu.my
}

construction in the project as developing the social and environmental impressions in construction. The fill soil is used to stabilize the Brick's waste. It improves the plasticity and strength of Bricks waste so the stable is ready to reuse in construction, consultation, and geotechnical engineering [6]. In Bhatta, production bricks are heated at 180-degree centigrade for 40 to 150 hours then the properties of clay change into solid, hard, and low absorption, consequence nonplastic soil is formed that will not be appropriate to use in highway embankment. If the cohesive soil is mixed, then plasticity of soil will be developed having increased load-bearing capacity $[7,8]$. It is also capable of resistance in seasonal variation moisture. Stabilization can be best characterized by mixing concerning atterberg limits and particle size distribution curve. Different trials and classification indicate the best-expected derivation for the suitability of the soil to enhance its shear strength and load-bearing capacity as desired requirement $[9,10]$.

Soil stabilization is the process to enhance the physical properties of 
soil by alteration and thus the stabilization can increase its engineering properties of soil as the shear strength of soil, ground improvement to support sub-grade, this can increase structural integrity, load-bearing capacity, and aging control of soil [11].

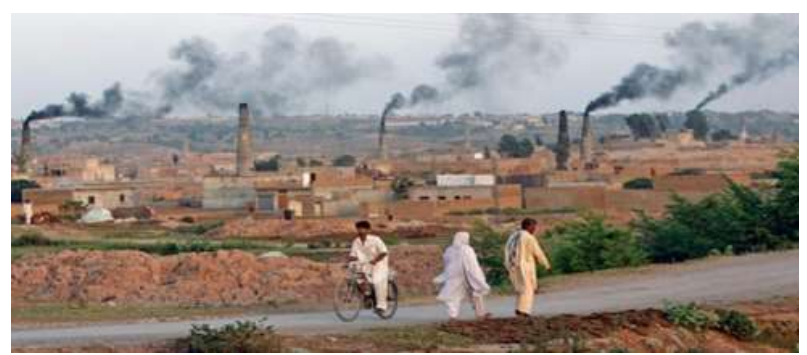

Fig. 1. Bricks Production and Environmental Pollution Waste

Bricks waste is bricks debris that emanates from the fundamental production of bricks. The building unit brick is composed of byproducts of cement, sand, clay, and water bonding as fired in the kiln. The three steps are performed in the production of the bricks after crushing, grinding, and filtering the raw material. This process includes shaping the brick in extrusion, molding, pressing, drying, and firing it $[12,13]$. During this process, the bricks develop cracks and become debris. When the bricks are heated at high temperatures some of them are cracked \& some of them are over-hearted burnt, increased in size, and unable to use so, these all are converted into Bricks waste [14]. During the bricks transportation, assembling, and drying then it becomes sticky, crushed and hit one another, and develop into Bricks waste. Bricks debris is the generation of construction and demolition waste expanse which is developed systematically during collection, transportation, and dumping of bricks. The debris is comprised of bricks, clay, soil, sand, and concrete $[15,16]$. The different vital properties of bricks debris are conveniently deliberated under physical, mechanical, durable, and thermal properties. In the debris, there are many forms of aggregate having different sizes but they are sieved by passing through sieve number 40 . Most debris is black-brown in shape. The density of which depends upon the clay material of bricks and it is approximately $1200 \mathrm{~kg} /$ cubic meter to $1600 \mathrm{~kg} /$ cubic meter [17]. In mechanical wise, bricks debris is strong in load-bearing and its compressive strength depends upon aggregate bounding. Thermally, bricks are fired under high temperatures and they conduct heat and porosity. Ideal bricks debris is strong and hard \& absorbs less water so that, debris can be used for insulation of heat but the durability of bricks debris depends upon the porosity or absorption value, frost resistance, and efflorescence [18].

Clay is a minuscule grained particle that is composed of one or more minerals of quartz, metal oxides, and organic matter made from natural rocks or other soil materials. The clay has plastic properties due to its magnitude and geometry [19]. The clay is fired or dried, so that it became hard and brittle altering from plastic to non-plastic properties. Clay has deposits of different grained particles as silts, clay, and sand but the clay particles consist of $40 \%$ minerals. The size distribution methods are put on to discriminate the silt and clay (clay is smaller in size as compared to silt) $[19,20]$. The geotechnical properties such as plasticity are determined through the Atterberg limit. Clay has different colors including deep red, white, brown \& orange light. Clay has a strong bearing capacity and strength when it is in hard form \& low bearing capacity in the soft form $[21,22,23]$.

\section{MATERIALS AND METHOD}

Following are the materials and methods discussed in this section.

\section{A. Fill Soil}

Fill soil is used to occupy the cavity created during excavation by heavy construction machinery in the high rise buildings. After the construction phase is done, the fill soil is dumped in the space created between the periphery of uncut soil and structure [24].

TABLE I

GEOTECHNICAL PROPERTIES OF VIRGIN FILL SOIL SAMPLE

\begin{tabular}{lll}
\hline \hline S. No. & Properties & Results \\
\hline 1 & Moisture Content (\%) & 6.38 \\
2 & Liquid Limit (\%) & 27 \\
3 & Plastic Limit (\%) & 15.70 \\
4 & Plasticity Index & 11.30 \\
5 & Specific Gravity & 2.56 \\
6 & Maximum Dry Density (gm/cc) & 1.78 \\
7 & Optimum Moisture Content & 16.29 \\
8 & USCS Classification & CL-ML \\
\hline \hline
\end{tabular}

\section{B. Brick Debris}

Brick debris is commonly found around the brick kiln and is generated usually during bricks transportation, placement and often can be obtained by crushing of bricks.

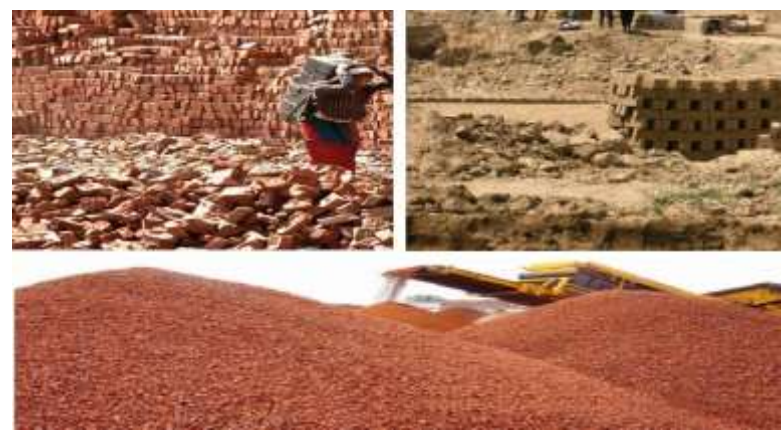

Fig. 2. Production of Bricks Waste

\section{Soil Sample Collection}

Cohesive/fill soil is taken from OPF block 5 housing society near japan road Islamabad, Pakistan. The brick debris is taken from a brick kiln near Naval Anchorage Islamabad. Both the brick debris and fill soil are oven-dried and crushed thereafter. Also, both the material is passed through sieve 40, and samples are prepared from it.

\section{Experimental Performance}

After obtaining soil sample for testing, initial tests of atterberg limits and sieve analysis were conducted for classifying soil to check its suitability which implied that our soil is lying in group CL-ML according to the unified soil classification system. Further on, more experiments were done on the soil like unconfined compression, direct shear, permeability, sieve analysis, and Moisture Dry Density (MDD) test after the admixture was added in 0, $5,10,15$, and $20 \%$ to improve its strength and depicting other changes in the soil characteristics. The fill soil is used for multiple purposes such as in pavement, foundation, and any subsequent filling, etc.

\section{RESULTS/FINDINGS}

Following are the different experiments performed on both virgin and modified CL-ML type fill soil and of which results are discussed as under: 


\section{A. Gradation Analysis}

The Gradation analysis curve of a virgin soil sample is shown in Figure 2. The soil sample is essentially a fine-grained material.

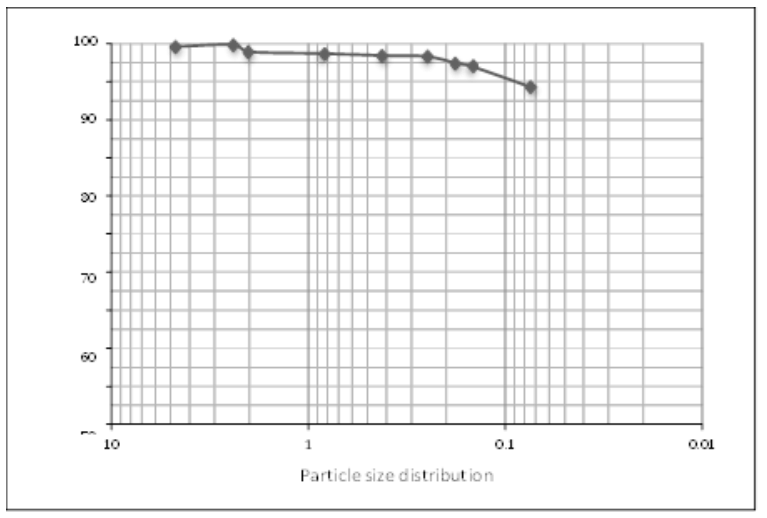

Fig. 3. Gradation Curve for Soil Sample Used in this Investigation

\section{B. Direct Shear Test}

Following are the results of the direct shear test performed on particularly CL-ML grouped soil sample For 0\% Debris.

TABLE II DIRECT SHEAR TEST 0\% DEBRIS

\begin{tabular}{lll}
\hline \hline $\begin{array}{l}\text { Normal Stress } \\
\left(\mathrm{kg} / \mathrm{cm}^{2}\right)\end{array}$ & $\begin{array}{l}\text { Peak Shear } \\
\text { Stress }\left(\mathrm{kg} / \mathrm{cm}^{2}\right)\end{array}$ & $\begin{array}{l}\text { Ultimate Shear } \\
\text { Stress }\left(\mathrm{kg} / \mathrm{cm}^{2}\right)\end{array}$ \\
\hline 0 & 0 & 0 \\
0.0277 & 0.51 & 0.35 \\
0.0555 & 0.64 & 0.51 \\
0.111 & 0.72 & 0.57 \\
\hline \hline
\end{tabular}

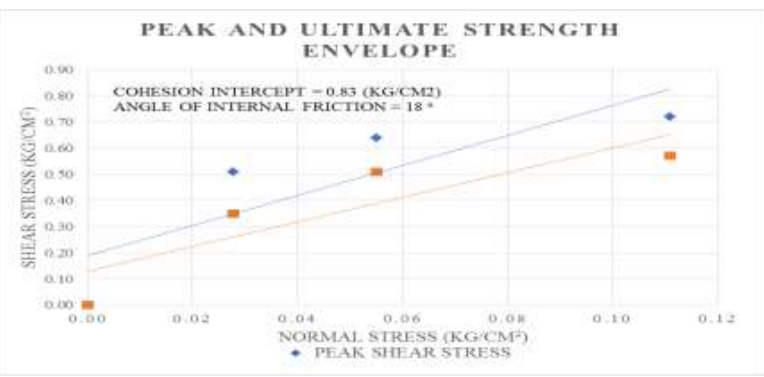

Fig. 4. Shear box-peak load 0\% debris

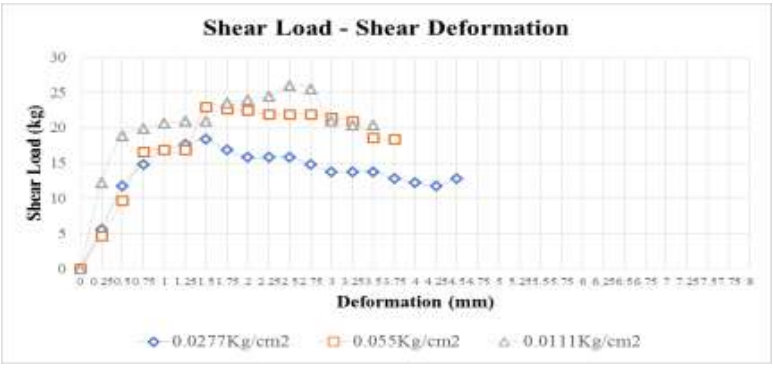

Fig. 5. Shear box-peak stress $0 \%$ debris
TABLE III DIRECT SHEAR TEST 5\% DEBRIS

\begin{tabular}{lll}
\hline \hline $\begin{array}{l}\text { Normal Stress } \\
\left(\mathrm{kg} / \mathrm{cm}^{2}\right)\end{array}$ & $\begin{array}{l}\text { Peak Shear } \\
\text { Stress }\left(\mathrm{kg} / \mathrm{cm}^{2}\right)\end{array}$ & $\begin{array}{l}\text { Ultimate Shear } \\
\text { Stress }\left(\mathrm{kg} / \mathrm{cm}^{2}\right)\end{array}$ \\
\hline 0 & 0 & 0 \\
0.0277 & 0.51 & 0.35 \\
0.0555 & 0.64 & 0.51 \\
0.111 & 0.72 & 0.57 \\
\hline
\end{tabular}

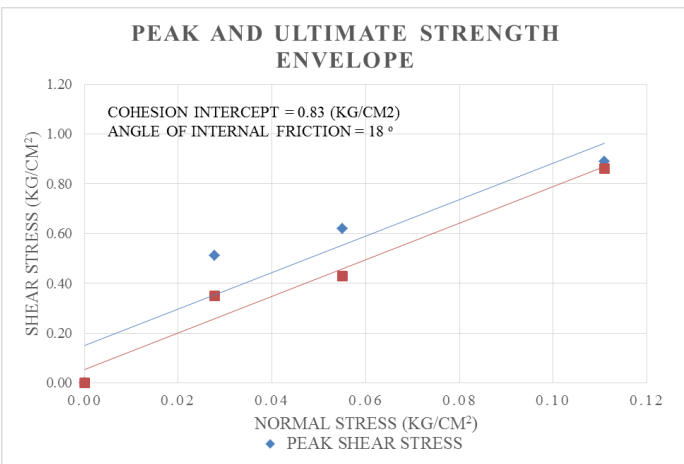

Fig. 6. Shear box-peak Load 5\% debris

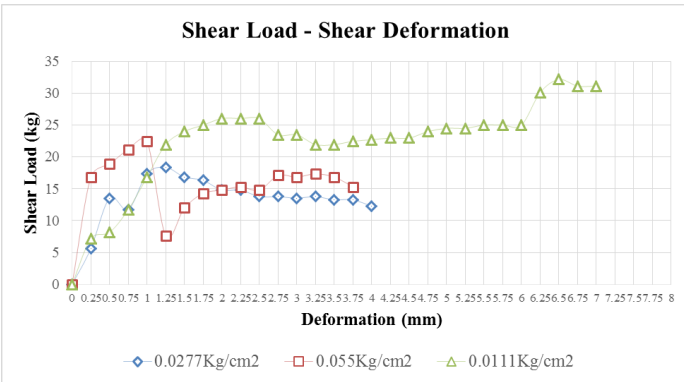

Fig. 7. Shear box-peak stress $5 \%$ debris

TABLE IV

DIRECT SHEAR TEST 10\% DEBRIS

\begin{tabular}{lll}
\hline \hline $\begin{array}{l}\text { Normal Stress } \\
\left(\mathrm{kg} / \mathrm{cm}^{2}\right)\end{array}$ & $\begin{array}{l}\text { Peak Shear } \\
\text { Stress }\left(\mathrm{kg} / \mathrm{cm}^{2}\right)\end{array}$ & $\begin{array}{l}\text { Ultimate Shear } \\
\text { Stress }\left(\mathrm{kg} / \mathrm{cm}^{2}\right)\end{array}$ \\
\hline 0 & 0 & 0 \\
0.0277 & 0.51 & 0.35 \\
0.0555 & 0.64 & 0.51 \\
0.111 & 0.72 & 0.57 \\
\hline \hline
\end{tabular}

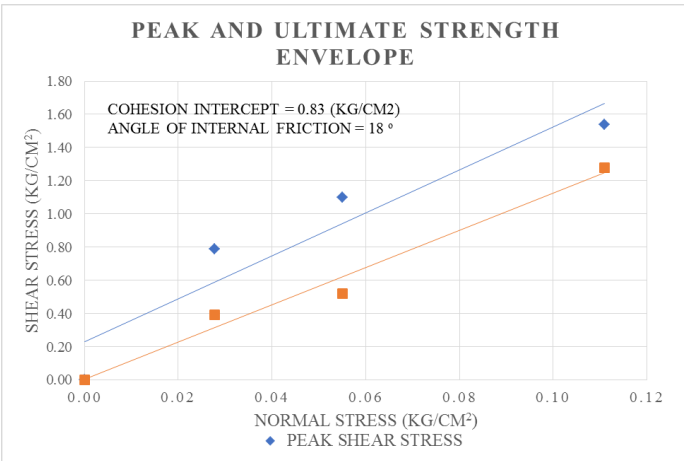

Fig. 8. Shear box-peak Load 10\% debris 


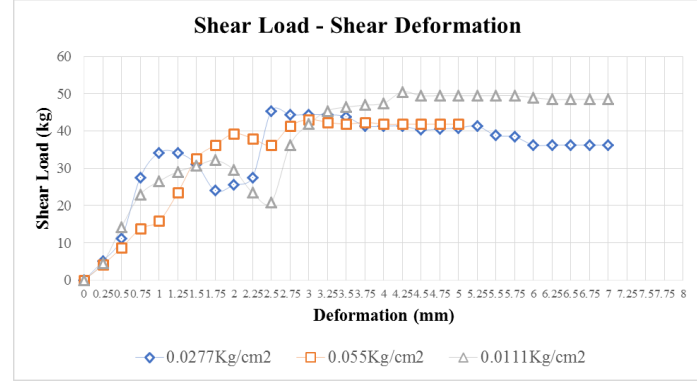

Fig. 9. Shear box-peak stress $10 \%$ debris

TABLE $V$

DIRECT SHEAR TEST 15\% DEBRIS

\begin{tabular}{lll}
\hline \hline $\begin{array}{l}\text { Normal Stress } \\
\left(\mathrm{kg} / \mathrm{cm}^{2}\right)\end{array}$ & $\begin{array}{l}\text { Peak Shear } \\
\text { Stress }\left(\mathrm{kg} / \mathrm{cm}^{2}\right)\end{array}$ & $\begin{array}{l}\text { Ultimate Shear } \\
\text { Stress }\left(\mathrm{kg} / \mathrm{cm}^{2}\right)\end{array}$ \\
\hline 0 & 0 & 0 \\
0.0277 & 0.51 & 0.35 \\
0.0555 & 0.64 & 0.51 \\
0.111 & 0.72 & 0.57 \\
\hline \hline
\end{tabular}

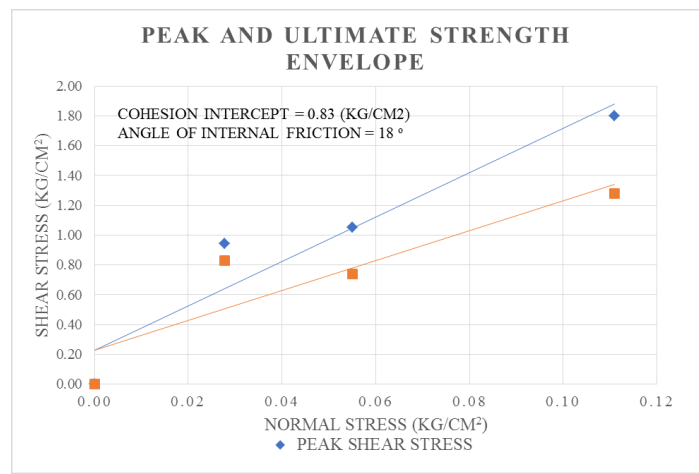

Fig. 10. Shear box-peak Load $15 \%$ debris

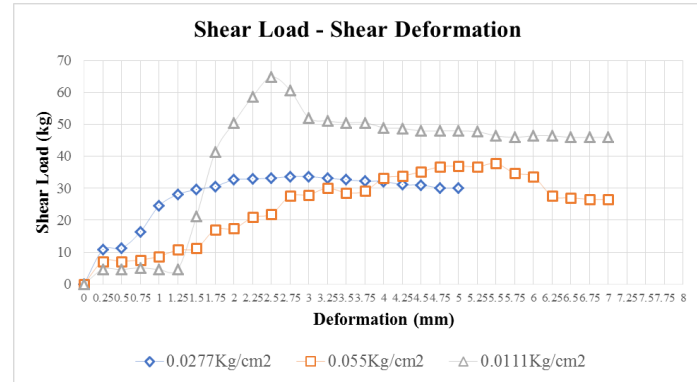

Fig. 11. Shear box-peak stress $15 \%$ debris

TABLE VI

DIRECT SHEAR TEST 20\% DEBRIS

\begin{tabular}{lll}
\hline \hline $\begin{array}{l}\text { Normal Stress } \\
\left(\mathrm{kg} / \mathrm{cm}^{2}\right)\end{array}$ & $\begin{array}{l}\text { Peak Shear } \\
\text { Stress }\left(\mathrm{kg} / \mathrm{cm}^{2}\right)\end{array}$ & $\begin{array}{l}\text { Ultimate Shear } \\
\text { Stress }\left(\mathrm{kg} / \mathrm{cm}^{2}\right)\end{array}$ \\
\hline 0 & 0 & 0 \\
0.0277 & 0.51 & 0.35 \\
0.0555 & 0.64 & 0.51 \\
0.111 & 0.72 & 0.57 \\
\hline \hline
\end{tabular}

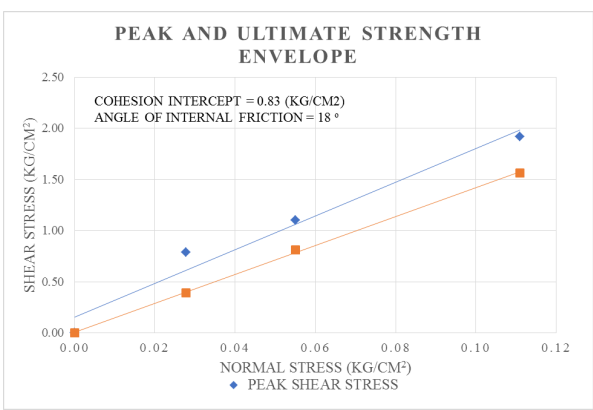

Fig. 12. Shear box-peak Load 20\% debris

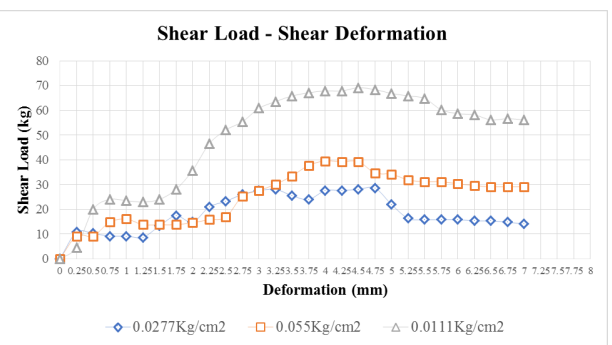

Fig. 13. Shear box-peak stress $20 \%$ debris

TABLE VII VARIATIONS OF L.L, P.L, AND P.I FOR SOIL AND BRICKS WASTE MIXES (DEBRIS)

\begin{tabular}{llll}
\hline \hline $\begin{array}{l}\text { Soil sample } \\
\text { + Debris (\%) }\end{array}$ & $\begin{array}{l}\text { Liquid Limit } \\
\text { (LL) \% }\end{array}$ & $\begin{array}{l}\text { Plastic \% } \\
\text { Limit (PL) \% }\end{array}$ & $\begin{array}{l}\text { Plasticity Index } \\
\text { (PI) \% }\end{array}$ \\
\hline $100+0$ & 27 & 15.7 & 11.3 \\
$95+5$ & 23.8 & 12.7 & 11.1 \\
$90+10$ & 23.5 & 12.7 & 10.7 \\
$85+15$ & 22.1 & 12.2 & 12.2 \\
$80+20$ & 25.6 & 16 & 9.6 \\
\hline \hline
\end{tabular}

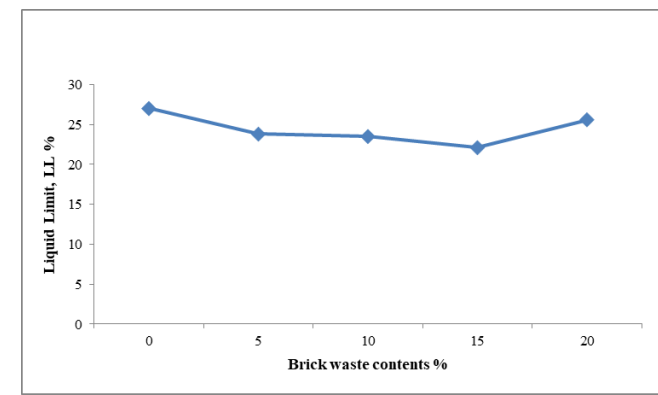

Fig. 14. Comparison of LL and Bricks Waste Content (Debris)

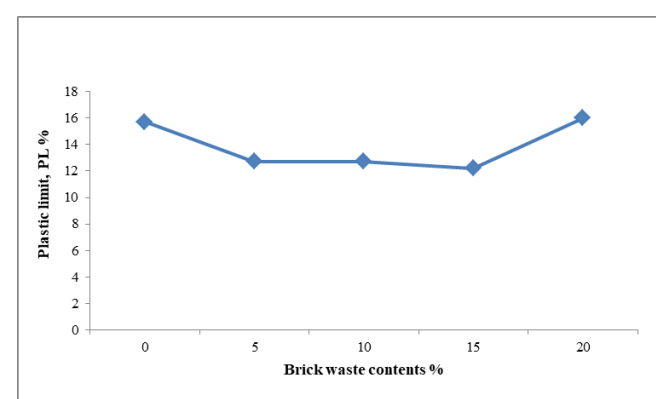

Fig. 15. Comparison of PL and Bricks Waste Content (Debris) 


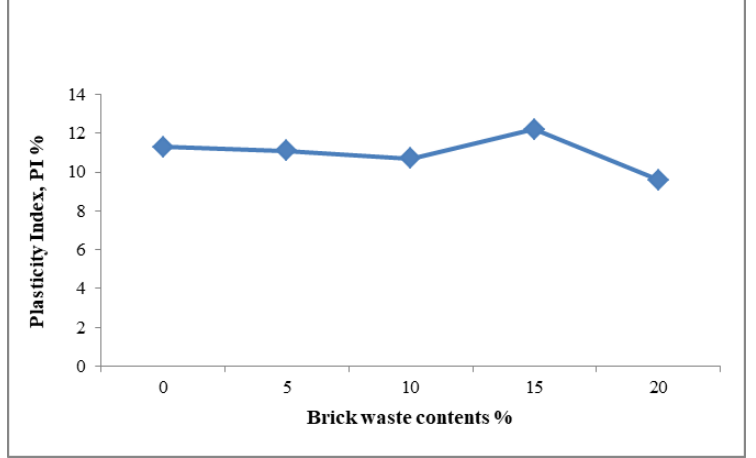

Fig. 16. Comparison of PI and Bricks Waste Content (Debris)

\section{COMPACTION CHARACTERISTICS}

The moisture content-dry density relationship of a given soil is determined by the Modified proctor test given as under:

TABLE VIII

VARIATION OF MDD AND OMC WITH THE PERCENTAGE OF BRICKS WASTE

\begin{tabular}{lll}
\hline \hline $\begin{array}{l}\text { Soil sample } \\
+ \text { Debris }(\%)\end{array}$ & $\begin{array}{l}\text { MDD } \\
(\mathrm{gm} / \mathrm{cc})\end{array}$ & $\begin{array}{l}\text { OMC } \\
(\%)\end{array}$ \\
\hline $100+0$ & 1.78 & 16.29 \\
$95+5$ & 1.91 & 15.8 \\
$90+10$ & 2.05 & 15.35 \\
$85+15$ & 2.13 & 14.92 \\
$80+20$ & 2.24 & 14.66 \\
\hline \hline
\end{tabular}

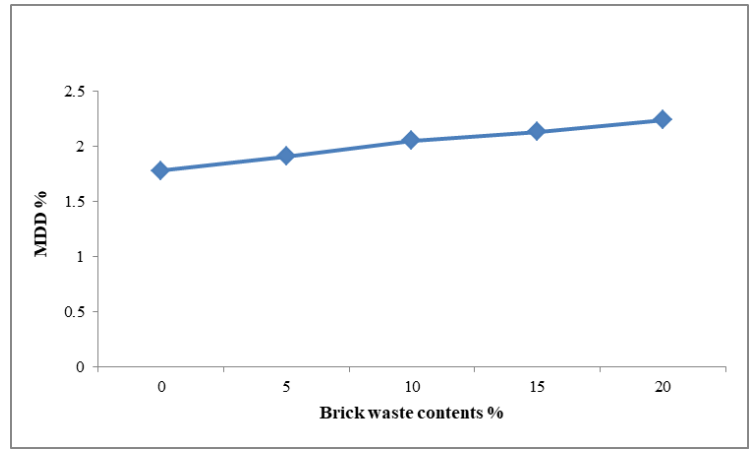

Fig. 17. Comparison of MDD and bricks waste content (Debris)

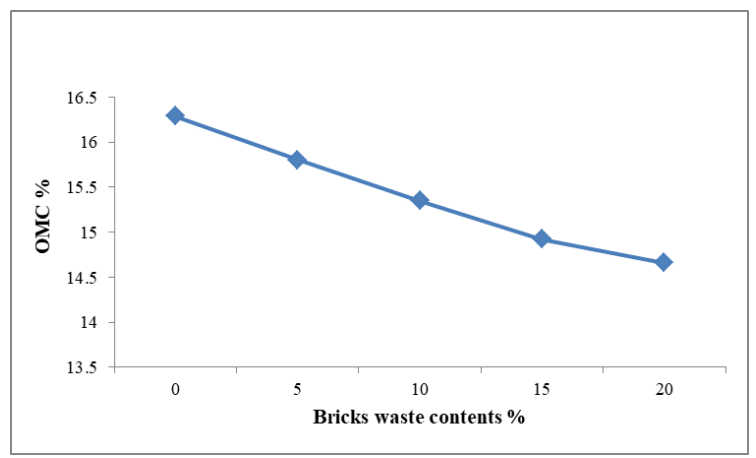

Fig. 18. Comparison of $\mathrm{OMC}$ and bricks waste content (Debris)

\section{A. Unconfined Compression Test}

Following are the results of the unconfined compression test performed on controlled fill soil sample along with samples having different percentages of debris contents.

TABLE IX

UNCONFINED COMPRESSION TEST RESULTS FOR DIFFERENT PERCENTAGES OF DEBRIS

\begin{tabular}{|c|c|c|c|c|c|c|c|c|c|}
\hline \multicolumn{2}{|c|}{ 0\% Debris } & \multicolumn{2}{|c|}{ 5\% Debris } & \multicolumn{2}{|c|}{$10 \%$ Debris } & \multicolumn{2}{|c|}{$15 \%$ Debris } & \multicolumn{2}{|c|}{$20 \%$ Debris } \\
\hline $\begin{array}{l}\text { Stress } \\
\left(\mathrm{kg} / \mathrm{cm}^{2}\right)\end{array}$ & $\begin{array}{l}\text { Deformation } \\
\Delta \mathrm{L}(\mathrm{mm})\end{array}$ & $\begin{array}{l}\text { Stress } \\
\left(\mathrm{kg} / \mathrm{cm}^{2}\right)\end{array}$ & $\begin{array}{l}\text { Deformation } \\
\Delta \mathrm{L}(\mathrm{mm})\end{array}$ & $\begin{array}{l}\text { Stress } \\
\left(\mathrm{kg} / \mathrm{cm}^{2}\right)\end{array}$ & $\begin{array}{l}\text { Deformation } \\
\Delta \mathrm{L}(\mathrm{mm})\end{array}$ & $\begin{array}{l}\text { Stress } \\
\left(\mathrm{kg} / \mathrm{cm}^{2}\right)\end{array}$ & $\begin{array}{l}\text { Deformation } \\
\Delta \mathrm{L}(\mathrm{mm})\end{array}$ & $\begin{array}{l}\text { Stress } \\
\left(\mathrm{kg} / \mathrm{cm}^{2}\right)\end{array}$ & $\begin{array}{l}\text { Deformation } \\
\Delta \mathrm{L}(\mathrm{mm})\end{array}$ \\
\hline 0 & 0 & 0 & 0 & 0 & 0 & 0 & 0 & 0 & 0 \\
\hline 0.02 & 0.2 & 0.05 & 0.2 & 0.03 & 0.2 & 0.08 & 0.2 & 0.09 & 0.2 \\
\hline 0.02 & 0.2 & 0.02 & 0.4 & 0.04 & 0.4 & 0.11 & 0.4 & 0.16 & 0.4 \\
\hline 0.04 & 0.4 & 0.02 & 0.6 & 0.07 & 0.6 & 0.13 & 0.6 & 0.2 & 0.6 \\
\hline 0.05 & 0.5 & 0.03 & 0.8 & 0.13 & 0.8 & 0.16 & 0.8 & 0.2 & 0.8 \\
\hline 0.05 & 0.6 & 0.02 & 1 & 0.15 & 1 & 0.17 & 1 & 0.21 & 1 \\
\hline 0.06 & 0.7 & 0.04 & 1.2 & 0.16 & 1.2 & 0.16 & 1.2 & 0.24 & 1.2 \\
\hline 0.08 & 0.9 & 0.05 & 1.4 & 0.17 & 1.4 & 0.18 & 1.4 & 0.25 & 1.4 \\
\hline 0.08 & 0.9 & 0.06 & 1.6 & 0.19 & 1.6 & 0.18 & 1.6 & 0.26 & 1.6 \\
\hline 0.11 & 1.2 & 0.07 & 1.8 & 0.2 & 1.8 & 0.18 & 1.8 & 0.3 & 1.8 \\
\hline 0.12 & 1.3 & 0.09 & 2 & 0.22 & 2 & 0.19 & 2 & 0.38 & 2 \\
\hline 0.14 & 1.5 & 0.12 & 2.5 & 0.25 & 2.5 & 0.22 & 2.5 & 0.42 & 2.5 \\
\hline \multirow[t]{3}{*}{0.12} & 1.3 & 0.14 & 3 & 0.27 & 3 & 0.27 & 3 & 0.47 & 3 \\
\hline & & & & & & 0.3 & 3.5 & 0.46 & 3.5 \\
\hline & & & & & & 0.29 & 4 & 0.43 & 4 \\
\hline
\end{tabular}




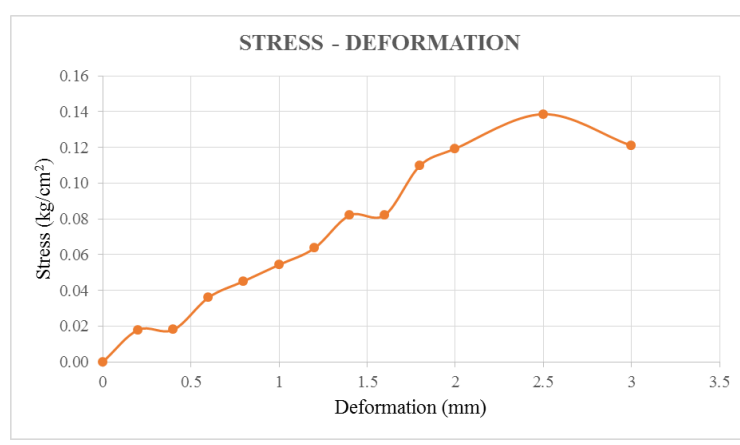

Fig. 19. Peak stress UCS 0\% debris

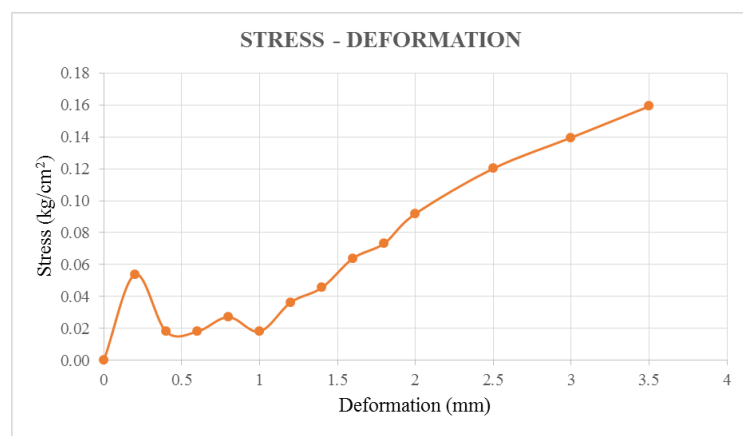

Fig. 20. Peak stress UCS 5\% debris

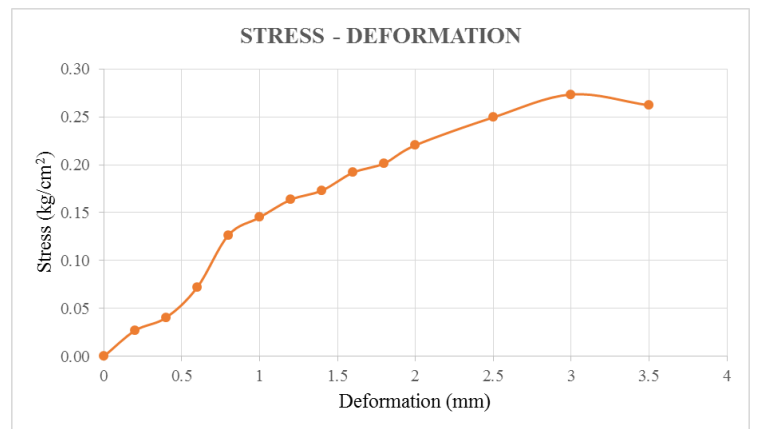

Fig. 21. Peak stress UCS $10 \%$ debris

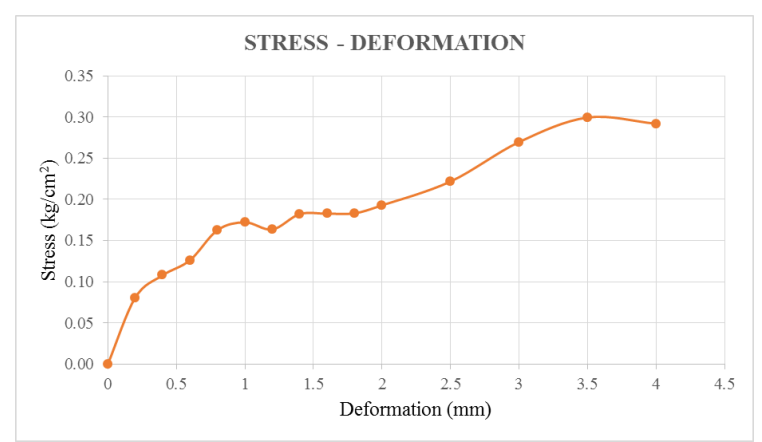

Fig. 22. Peak stress UCS 15\% debris

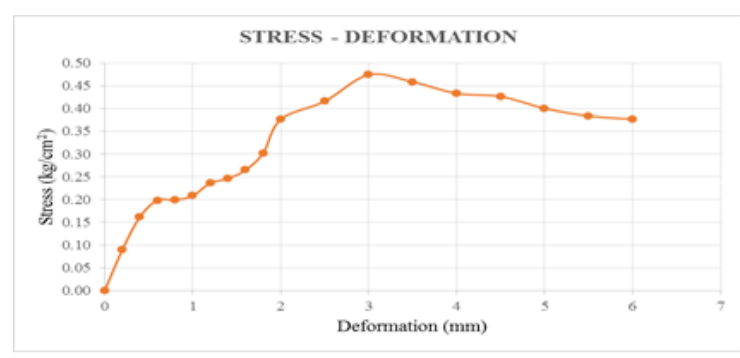

Fig. 23. Peak stress UCS $20 \%$ debris

\section{CONCLUSION}

Following are the conclusions derived from the experimentation performed on fill soil with waste bricks contents utilization.

- Atterberg limits data shown a marginal effect on plasticity after $10 \%$ and soil is classified as MH-CH from CL-ML. The MH-CH soil is toughness-wise improved soil having more stiffness property as compared to CL-ML.

- Sieve analysis results indicated the replacement of fines occurred. It means that the smaller particles are replaced with bigger particles as we move on to higher percentages of $20 \%$ debris. It also results in more amount of material retained on sieve no 200.

- Unconfined compression test results show a pattern in which the peak stress is increased as we move to higher percentages. Also, the moisture content is increased for this test because the brick debris absorbed water, as a result of which samples were broken previously and an increase of moisture became obligatory.

- Direct shear test on percentages up to $15 \%$ showed that the peak shear stress increased, which indicates that on higher percentages the sample took more load as compared to small percentages.

- During the Permeability test, no drainage of water occurred through the sample indicating it was highly impermeable. Although at the higher percentages, a small quantity of water drained but it's not sufficient for test conduction.

- Moisture Dry Density relationship provides a clear indication of an increase in density of soil as moved to higher percentages and decrease in OMC which suggests that, clay absorbs more water content as compared to brick debris.

\section{ACKNOWLEDGMENT}

First and foremost, we would like to thank Allah Almighty who always helped us throughout our lives and to get through this research degree and thesis. We would like to pay the debt of gratitude to Mr. Muhammad Arif Gondal (Late), Founder of MHU Builders Islamabad, Pakistan for his profound guidance, and encouragement, to complete this research work. We are also thankful to our civil engineering department without their involvement and constant support this project could never have been accomplished. And in the end, we would like to pay my earnest and honest gratitude to our family, especially for their unconditional support, encouragement, prayers, and patience. 


\section{References}

[1] M. Pagliai and N. Vignozzi, "Use of manures for soil improvement," in Handbook of soil conditioners. Boca Raton, FL: CRC Press, 2020.

[2] N. Latifi, A. Eisazadeh, A. Marto, and C. L. Meehan, "Tropical residual soil stabilization: A powder form material for increasing soil strength," Construction and Building Materials, vol. 147, pp. 827-836, 2017. doi: https://doi.org/10.1016/j.conbuildmat.2017.04.115

[3] Y. Tsukamoto, "Degree of saturation affecting liquefaction resistance and undrained shear strength of silty sands," Soil Dynamics and Earthquake Engineering, vol. 124, pp. 365-373, 2019. doi: https: //doi.org/10.1016/j.soildyn.2018.04.041

[4] A. Seco, J. Omer, S. Marcelino, S. Espuelas, and E. Prieto, "Sustainable unfired bricks manufacturing from construction and demolition wastes," Construction and Building Materials, vol. 167, pp. 154-165, 2018. doi: https://doi.org/10.1016/j.conbuildmat.2018.02.026

[5] Z. Hussain and S. Ali, "Comparative study on breaking strength of burnt clay bricks using novel based Completely Randomized Design (CRD)," Civil Engineering Journal, vol. 5, no. 5, pp. 1162-1174, 2019. doi: https://doi.org/10.28991/cej-2019-03091320

[6] M. Priyadarshini, J. P. Giri, and M. Patnaik, "Variability in the compressive strength of non-conventional bricks containing agro and industrial waste," Case Studies in Construction Materials, vol. 14, pp. 1-11, 2021. doi: https://doi.org/10.1016/j.cscm.2021.e00506

[7] A. Geremew and Y. Mamuye, "Improving the properties of clay soil by using laterite soil for production of bricks," Civil and Environmental Engineering, vol. 15, no. 2, pp. 134-141, 2019. doi: https: //doi.org/10.2478/cee-2019-0017

[8] G. T. Demirkol, M. Ozcoban, and N. Tufekci, "Removal rate of compacted clay soil in the batch and continuous reactors and its permeability," Journal of Advances in Technology and Engineering Research, vol. 3, no. 5, pp. 176-183, 2017. doi: https://doi.org/10. 20474/jater-3.5.2

[9] C.-c. Chang, D.-h. Cheng, and X.-y. Qiao, "Improving estimation of pore size distribution to predict the soil water retention curve from its particle size distribution," Geoderma, vol. 340, pp. 206-212, 2019. doi: https://doi.org/10.1016/j.geoderma.2019.01.011

[10] Z. Demir, "Effects of vermicompost applications on atterberg limits and workability of soils under different soil moisture contents," Eurasian Journal of Soil Science, vol. 10, no. 3, pp. 215-221, 2021. doi: https://doi.org/10.18393/ejss.888643

[11] A. Patel, Geotechnical investigations and improvement of ground conditions. Sawston, UK: Woodhead Publishing, 2019.

[12] N. Hossiney, P. Das, M. K. Mohan, and J. George, "In-plant production of bricks containing waste foundry sand-a study with Belgaum foundry industry," Case Studies in Construction Materials, vol. 9, pp. 1-25, 2018. doi: https://doi.org/10.1016/j.cscm.2018.e00170

[13] H. Slimanou, D. Eliche-Quesada, S. Kherbache, and N. Bouzidi, "Harbor dredged sediment as raw material in fired clay brick production:
Characterization and properties," Journal of Building Engineering, vol. 28, pp. 1-42, 2020. doi: https://doi.org/10.1016/j.jobe.2019. 101085

[14] J. Akinyele, U. Igba, and B. Adigun, "Effect of waste PET on the structural properties of burnt bricks," Scientific African, vol. 7, pp. 1-8, 2020. doi: https://doi.org/10.1016/j.sciaf.2020.e00301

[15] M. M. Atyia, M. G. Mahdy, and M. Abd Elrahman, "Production and properties of lightweight concrete incorporating recycled waste crushed clay bricks," Construction and Building Materials, vol. 304, pp. 1-17, 2021. doi: https://doi.org/10.1016/j.conbuildmat.2021. 124655

[16] M. Attom, M. Kou, and N. Al-Akhras, "Geo environmental utilization of iron-filing with cement in soil stabilization," International Journal of Technology and Engineering Studies, vol. 2, no. 2, pp. 32-37, 2016. doi: http://dx.doi.org/10.20469/ijtes.2.40001-2

[17] Y. Khalid Khdir and G. Ismail Hassan, "Use of different graded brass debris in epoxy-resin composites to improve mechanical properties," Eurasian Journal of Science and Engineering, vol. 3, no. 3, pp. 124-131, 2018.

[18] I. Rörig-Dalgaard and A. Charola, "Evaluation of fired clay bricksextent of decay," in 1st International Conference on Moisture in Buildings, London, UK, 2021. doi: https://doi.org/10.14293/ICMB210057

[19] Y. Wu, Y. Li, S. Luo, M. Lu, N. Zhou, D. Wang, and G. Zhang, "Multiscale elastic anisotropy of a shale characterized by cross-scale big data nanoindentation," International Journal of Rock Mechanics and Mining Sciences, vol. 134, pp. 1-18, 2020. doi: https://doi.org/10.1016/ j.ijrmms.2020.104458

[20] S. Salihu and I. Suleiman, "Comparative analysis of physical and chemical characteristics of selected clays deposits found in Kebbi State, Nigeria," International Journal of Physical Sciences, vol. 13, no. 10, pp. 163-173, 2018. doi: https://doi.org/10.5897/IJPS2018. 4727

[21] H. E. B. El Idrissi, L. Daoudi, M. El Ouahabi, F. Collin, and N. Fagel, "The influence of clay composition and lithology on the industrial potential of earthenware," Construction and Building Materials, vol. 172, pp. 650-659, 2018. doi: https://doi.org/10.1016/j. conbuildmat.2018.04.019

[22] I. Abidi, L. Benamara, A. A. S. Correia, M. Pinto, and P. P. Cunha, “Characterization of dredged sediments of Bouhanifia dam: potential use as a raw material," Arabian Journal of Geosciences, vol. 14, no. 23, pp. 1-16, 2021. doi: https://doi.org/10.1007/s12517-021-08742-4

[23] M. S. Khan, M. Tufail, and M. Mateeullah, "Effects of waste glass powder on the geotechnical properties of loose subsoils," Civil Engineering Journal, vol. 4, no. 9, pp. 2044-2051, 2018. doi: https://doi.org/ 10.28991/cej-03091137

[24] M. Ali Musarat, W. Salah Alaloul, and M. S. Liew, "Construction machinery hire rates deviation in Malaysia: An inflation rate effect analysis," Revista De La Construcción, vol. 20, no. 1, pp. 91-105, 2021. doi: http://dx.doi.org/10.7764/rdlc.20.1.91 